\title{
The Effect of Macroeconomic Variables on Industry Sector Output Growth of Ethiopia
}

\author{
Adisu Abebaw \\ Department of Economics, College of Business and Economics, Salale University, Fiche, Oromia Region, Ethiopia \\ Email address: \\ adisuaad@gmail.com \\ To cite this article: \\ Adisu Abebaw. The Effect of Macroeconomic Variables on Industry Sector Output Growth of Ethiopia. International Journal of Business \\ and Economics Research. Vol. 8, No. 6, 2019, pp. 325-338. doi: 10.11648/j.ijber.20190806.11
}

Received: July 9, 2019; Accepted: July 30, 2019; Published: September 20, 2019

\begin{abstract}
Industrialization plays a key role in the process of a nation's economic development. The experience of the developed world revealed that industrialization significantly increased their productivity and changed the economic structure. Mainly with the context of reoccurring unstable macroeconomic performance in Ethiopia, analyzing the effect of macroeconomic variables on industry sector output growth is a proper way to design suitable industrial policies. Therefore, this study aimed to examine the effect of some macro-economic variables on the industry output growth in Ethiopia. To do so the study used a time series data ranging from 1991 up to 2018 from Ministry of Finance and Economic Cooperation of Ethiopia. The study also used Augmented Dickey-Fuller (ADF) and the Phillip-Perron (PP) unit root tests of stationary, Auto Regressive Distributed Lag (ARDL) bound test to co-integration and error correction model. Accordingly the study confirmed the existence of a long-run relationship between industrial output growth and macroeconomic variables. Macroeconomic variables such as, lending rate, inflation rate and trade balance found to be affecting the industrial sector output growth negatively, positively and negatively, respectively in the long run. Therefore, the government has to keep lending rate to the level that could be amenable for firms and maintaining the trade balance; via manipulating the export and import.
\end{abstract}

Keywords: Bound Test, Industrial Output, Macroeconomic Variables, Lending Rate

\section{Introduction}

\subsection{Background of the Study}

Industrialization is a process by which industries are introduced and expanded in a particular place or country [43]. Industrialization also refers to an increase in the share of industrial sector in the total output and total employment in economy. Industrialization plays a key role in the process of a nation's economic development [44]. It brings about an increased volume and varieties of manufactured goods resulting in increased employment and improved standard of living of the citizens [23]. The development of the industrial sector stimulates economic development by eradicating poverty, increasing hard currency earning, creating employment opportunity and augmenting technological capabilities [40]. The experience of the developed world revealed that industrialization significantly increased their productivity and changed the economic structure [18]. Especially the experience some countries such as South
Korea, Malaysia and Singapore shows that industrialization has played a crucial role in transforming their economy [34].

Industrialization can; create employment opportunities, provides; different farm inputs so as to increase productivity in the agricultural sector, brings increasing returns and economies of scale [16]. Acquisition of industrial capabilities by an economy is seen as a potential for rapid and improve economic growth and development [3]. However, the economies of African countries including Ethiopia are characterized by the predominance of the agricultural sector; in terms of production and export of primary commodities [34], while the modern industrial sector is nearly stagnant [41]. The Ethiopian industrial sector covers not more than 17 percent of the country's gross domestic product and more than $70 \%$ of Ethiopia's population is still engaged in agricultural sector [2].

Industrialization in Ethiopia was relegated to a secondary status by Agriculture Development Led-Industrialization (ADLI) strategy [18], whose prime intention is to encourage the interrelationship between industrial and agricultural 
sectors [9]. Agricultural expansion is supposed to be the springboard for industrialization. However the subsequent national growth plans such as GTP I \& II have laid its intention in augmenting the overall economic growth via industrialization [2]. Especially from 2000 onwards the country has pursued an active industrial policy with a large set of carefully designed policy instruments which include the promotion of exports and productive investment, industrial financing, and the use of state-owned enterprises to shape strategic sectors [33]. Among others, the instrument of industrial policy may extend; subsidies, tax incentives, export promotion and import restrictions [23].

However, industrial sector output growth can be affected by different monetary policy transmission mechanism [20]. This mechanism operates through such as lending rate (interest rate), inflation rate, real effective exchange rate, exchange rates, equity and real estate prices and firm balance sheets. These in turn affect the decisions of firms, households, financial institutions and investors [13]. For instance an increase in the interest rate leads to a higher cost of borrowing, this results lower level of private investment [26] and consequently results in a fall in total output.

An increase in money supply would cause interest rates to fall [5] which further results investment to rise. a fall in the exchange rate (decrease in the value of domestic currency) also makes domestic goods cheaper compared to imported goods, thus resulting to an increase in net exports leading to an increase in output, while the reverse is true [24].

Therefore for a proper design of growth enhancing policies, policy makers should know the production structures and factors underlying them in the economy. Analyzing the factors affecting industrial growth is an appropriate way of finding where policies can rightly respond to these issues. With the context of reoccurring unstable macroeconomic performance (higher inflation rate, deteriorating trade balance and devaluation of domestic currency) in recent times, it is worthwhile to understand the effect of macroeconomic variables on industry sector growth. However there is a limited study has conducted in the area. [2] Studied the intersectoral linkages in Ethiopian economy using a time series data ranging from 1975 to 2017 . He found that, Industrial output growth is largely depends on agricultural and service sectors. [45] studied the interrelationship between agriculture and industry and they found the long-run causality running from industry to agriculture was found. Accordingly this paper examined the effect of macroeconomic variables on Ethiopian industrial output growth using a time series data ranging from 19912018.

\subsection{Objective of the Study}

The general objective of the study is to investigate the effect of macroeconomic variables on industrial sector output growth of Ethiopia and specifically to;

a) Explore the long-run relationship between macroeconomic variables and industrial sector output growth. b) Examine the effect of macroeconomic variables in the long-run and short-run industrial output growth.

\section{Literature Review}

\subsection{Theoretical Literature Review}

The theory of infant industry contends that lack of productive capabilities is the main cause of underdevelopment and augmenting such capabilities are essential for economic development. The major argument this theory is that protecting infant industries from superior competitors provides domestic markets. Ultimately this leads the infant producers to enjoy scale economies, making them more cost-efficient and thus greater production experiences lead to acceleration in productivity growth [7]. The notion of comparative advantage was first systematically developed by David Ricardo. Having comparative advantage in something simply means that of all the possible activities it could be conducting, the country is the best at that activity. The beauty of the concept is that, even if a country is the most (least) efficient in producing everything, it will still benefit from trading with other countries, because specializing in the products in which it is the most good at (or the least bad at) allows it to maximize its output and, through international trade, consumption. It follows that any industrial policy that tries to promote industries in which the country does not have comparative advantage is harmful [7].

There are limited theories directly linked the macroeconomic variables with respect to the industrial sector. The relationships between industrialization, particularly manufacturing and economic growth can be captured by Kaldors growth laws. [15], noted that the link between industrial growth and the performance of the economy as a whole was imperative for the growth path of developed economies [12] sustained economic growth is strongly related to industrialization. Kaldor's three basic growth laws have been tested widely discussed on literature. The first law says that there exists a strong positive relationship between the manufacturing output growth and the growth of the GDP. This law is summed up by the statement that manufacturing is the engine of growth.

According to [15], the output growth in non-manufacturing sector can responds to the growth of manufacturing output for two reasons. The first reason is that the expansion of manufacturing leads to the transfer of labour from the low productivity areas to industrial activities. The second one is the existence of returns to scale in the manufacturing and hence, in industrial sector. The economies of scale internal to the firm and the increasing productivity arise through technology and ongoing on-the-job training [22].

The second law, also known as Verdoorn's law, states that there exists a strong positive correlation between output and labour productivity growth in manufacturing (hence industry) sector. When manufacturing output increase so does manufacturing labour productivity. An initial growth in output is expected to induce productivity gains which allow 
for a reduction of unit labour costs and consequently a fall in prices [22].

The third law states that there exists a strong positive relationship between the manufacturing output growth and non-manufacturing productivity growth. The basic premise here is the non-industrial sector (such as traditional agricultural sector) has diminishing returns to scale and as such, when resources transfer to the industrial sector, the average productivity of those that remain will eventually rise [12].

There are different theories discussing on the relationship between GDP and the various nominal macroeconomic variables. Theories such as; the Okun law, Phillips Curve, Keynesian, monetarist and monetary policy indeed, can be compressed both the finance-led growth hypothesis (also known as supply-leading) and the demand-following responses [1]. The former states that the development of the financial sector of the economy propels the real sector and accelerates the growth of the economy through facilitation of physical and human capital accumulation and, raising the rate of technological progress [28]. This hypothesis assumes that the intermediation activities of the financial institutions make the real sector to increase their productive capacity, which subsequently enlarges the productive base of the economy [39].

The proponents of demand following hypothesis assume that the enlargement of the economy pushes the real sector to demand for fund from the financial institutions to meet up with the increase in productivity [39]. When an economy starts to grow it creates immediate additional demand for financial services and helps grow a better financial system [27]. Ultimately this may lead to increased confidence in the economy and encourage additional foreign direct investments. Foreign direct investments in turn stimulate host country industrial growth by transferring technology and restructuring industrial sector [40]. However, as long as economic growth is concerned; there is the need for stability in macro-economic environment which is characterized with low risk and a condition for attracting investment (both domestic and foreign) and boosting entrepreneurial activities. There is therefore the need to keep interest rate and inflation at a manageable limit in an environment of stable exchange rate regime [1].

\subsection{Review of Empirical Literature}

There are a numbers of empirical studies, which have recorded the relationships of macroeconomic variables and industrial sector. [4] studied the determinants of industrialization of 35 African countries. Using a time series data ranging from 1970-2012 and dynamic panel model, their study revealed that Human capital, Labor Market conditions, Real Effective Exchange Rate and GDP per capita are found to be the determinants of industrialization in Africa. Moreover, the study depicted that the determinants of industrialization vary between regions in the continent and evolve over time.

The study [8] Also investigated the impact of macroeconomic factors on manufacturing productivity in Nigeria over the period 1975-2011. Using error correction mechanism model, the study assured the presence of a longterm equilibrium relationship, show that credit to the manufacturing sector in the form of loans and advances and foreign direct investment have the capacity to sharply increase the level of manufacturing productivity in Nigeria, while broad money supply has less impact. [32] estimated the response of manufacturing capacity utilization in Nigeria to changes in key macroeconomic indicators using annual data over the period 1975 - 2012. Accordingly a co-integration between the endogenous and exogenous variables was found and variations in manufacturing capacity utilization in Nigeria are largely driven by its own shocks. The study further shows that exchange rate; interest rate and terms of trade contribute significantly but negatively to variations in manufacturing capacity utilization. The study also presents evidence of causal impact of manufacturing capacity utilization on exchange rate and manufacturing capacity utilization on interest rate and not vice versa.

The study [6] Analyzed the drivers of successful industrialization in developing countries. Consider two different periods (1970-1990 and 1991-2014). The empirical analysis reveals that successful industrialization is driven by a combination of factors, including the country's initial economic conditions, its factor endowments as well as other characteristics, such as demographic structure and geography. The study also shows that other variable such as; the promotion of investments in capital and education; the management of trade and capital openness; financial sector development and the promotion of both macroeconomic and institutional stability, which policymakers can control, play a crucial role. [3] examined the effect of bank credit finance and other macroeconomic policy variables on industrial output in Nigeria. Using an Ordinary Least Square (OLS) regression technique and time series data extended from 1980-2010, the study revealed that install capacity utilization rate, previous industrial output, inflation rate and political instability significantly influenced industrial output in Nigeria. The study recommended, to boost industrial output, there is need to pursue policies that would enhance the capacity utilization rate of industries, as well as ensuring the provision of bank credit finance at affordable interest rate and less stringent conditions.

The study [42] Empirically assessed the impact of monetary policy on industrialization in Nigeria. Using vector error correction mechanism of ordinary least squares estimation technique and time series variables. The study revealed that exchange rate, interest rate, money supply, balance of trade, and total reserves variables have statistically significant impact on industrialization. The study suggested that monetary policy should be consistent and transparently defined in response to the dynamics of the domestic and global economic developments. [38], by using both inflation and terms of trade as additional exogenous covariates in a panel model explaining economic growth in manufacturing sector, finds a negative and significant relationship between 
economic growth and inflation in developing countries. [40] investigated the relationship between FDI and industrial sector performance of Sri Lanka for the period 1980-2016. Using Auto Regressive Distributed Lag (ARDL) their study proved the existence of co-integration among the selected variables but failed to find a significant relationship between FDI and industrial sector growth both in the long run as well as in the short run.

\subsection{Industrial Policy in Ethiopia}

Industrial policy can be defined as a systematic government involvement through specifically designed policies in industrial affairs, arising from the adequacy of macroeconomic policies in regulating the growth of the industry [23]. Basically Industrialization in Ethiopia is largely a post WWII phenomenon and underwent evolution throughout the Imperial era, the Derg military regime (19751991), and the post-1991 period [33].

\subsubsection{Industrialization in the Imperial Era (1930-74)}

At the time of Imperial era (1950 to 1974) Import substitution industrialization strategy and supporting policies were used [33]. Through the medium term plans with the underpinning import substitution industrialization strategy, the government attempted to promote industrial sector development. The manufacturing sector was identified as the key sector for transforming the structure of the economy and for achieving a rapid and sustained growth. The investment decree of 1962 which offered an exemption from profit tax for five years, guaranteed remittances, duty-free machine imports, and equity participation in local firms was the first serious attempt made by the regime [18], albeit it was not applicable for Ethiopians [33].

\subsubsection{Industrialization in the Derg Regime (1975-91)}

Latter on the 1974 Ethiopian revolution has changed both the political landscape and the economic policy orientation of the country. The revolution has profoundly affected the manufacturing industries [33]. Different major manufacturing establishments were nationalized by the government nationalized [18]. During the Derg regime, Priority was given to the defense industry and capital investment was geared towards defense needs [33] and the private sector was excluded from the economy and the government had emerged as a dominant economic actor.

\subsubsection{Industrialization in the EPDRF Era (1991-)}

In1991 the Ethiopian People's Revolutionary Democratic Front (EPRDF) held power. Addressing the crisis in agriculture was a fundamental concern of the day, with agricultural recovery also seen as a spark for renewed commitment to industrialization. The industrial development strategy and practice of the administration is summed as a market oriented; private driven but with a strong state; dominance of domestic private owned enterprises; export oriented and labor intensive industries; including direct support for selected industries [29].

Later on, the government adopted the overall development strategy known as Agriculture Development LedIndustrialization (ADLI) [9]. The strategy gives special attention for the agriculture sector; it sets as a primary stimulus to generate increased output, employment, and income for the people, and as the springboard for the development of the other sector of the economy [16]. In this regard Industrialization was relegated to a subordinate status. Ethiopia has been implementing different successive development plans through which The industrial policy framework concretized; such as; sustainable development and poverty reduction program (SDPRP), Plan for Accelerated and Sustained Development to End Poverty (PASDEP), Growth and Transformation Plan (GTP I) and Growth and Transformation Plan (GTP II).

Ethiopia's Growth and Transformation Plan (GTP I) was a medium term strategic framework for the five-year period (2010/11-2014/15). Among others, the plan were supposed to maintain agriculture as a major source of economic growth and creating favorable conditions for the industry to play key role in the economy in determining the overall growth [25]. The second growth and transformation plan (GTP II) plan which is to be implementing from $2015 / 16$ to $2019 / 20$. The principal objective of GTPII is to sustain the accelerated growth and establish a spring board for economic structural transformation and thereby realizing the national vision of becoming a lower middle-income country by 2025 . Modernization in the development of the agriculture sector, expansion of industrial development with primary focus on light manufacturing, significant shift in export development are at the core of GTPII.

According to [31], in GTPII period agriculture also remains the main driver of the rapid and inclusive economic growth and development. Thus, GTP I and II contain objectives aimed to execute the principles of ADLI. However, it is fair to say that, these development plans never give due attention for the industrial sector unlike the agricultural sector [25]. The EPRDF increasingly pursued the development of the manufacturing sector as the prime driver of sustained economic growth and structural transformation post 2010 [33].

\section{Data and Methodology of the Study}

\subsection{Data Type and Sources}

The study used a secondary time series data ranging from 1991 up to 2018. The data are obtained from Ministry of Finance and Economic Cooperation (MoFEC) of Ethiopia. The rationale for using data started from 1991 is due to the secession Eritrea from Ethiopia. And most macroeconomic time series data before 1991 of Ethiopia are found amalgamated with Eritrea's. This study used both empirical and descriptive type of research in order to assess the effect of macro-economic variables on industrial output of Ethiopia and the data are based on 2011 constant price.

\subsection{Model Specification and Estimation Procedure}

In macroeconomics aggregate production functions are 
estimated to create a framework in which to distinguish how much economic growth to attribute to change in the factor allocation and advancing technology. From the literature, the Cobb- Douglas production function through the application of Auto Regressive Distributed Lag (ARDL) model is adopted to examine the effects of macroeconomic variables on industrial outputs of Ethiopia.

$$
\mathrm{Y}=\mathrm{f}(\mathrm{L}, \mathrm{K}, \mathrm{A})
$$

The importance of productivity factor A (which is a technology or any other factor which affect long run growth in addition to Labor and Capital) is augmented in the production function. To empirically find the effect of macroeconomic variables on industrial output of Ethiopia, the study uses the Bound test of co-integration technique and error correction model. But before the application of ARDL model, the variables need to be tested whether they are stationary at level (0) or at first difference (I).

\subsubsection{Unit Root Test}

In statistics and econometrics, an Augmented DickeyFuller test (ADF) is a test for a unit root in a time series samples. It is an augmented version of the Dickey-Fuller test for a larger and more complicated set of time series models [17]. The ADF is a widely used test in time series analysis, and was developed from the Dickey-Fuller (DF) test. The study use it might seem reasonable to test the existence of a unit root in the series using the most general of the models.

To determine whether the data is stationary or not we use the popular form of checking the stationary property of the variables is the Augmented Dickey Fuller (ADF) unit root test. As a result of this test the following decision rule is formulated.

If $\left|t^{*}\right|>|\mathrm{ADF}|$ critical value, $==>$ not reject null hypothesis, and unit root exists.

If $\left|t^{*}\right|<|\mathrm{ADF}|$ critical value, $==>$ reject null hypothesis, and unit root does not exist.

Where: - $t^{*}$ is ADF-test Statistics, that is calculated value and ADF critical value is value of ADF at standard level of significances, i.e., at $1 \%, 5 \%$ and $10 \%$ significance levels.

Another technique of testing stationary is the PhillipsPerron (PP). The Phillips-Perron (PP) [37] test is well suited for analyzing time series whose difference may follow mixed autoregressive moving average $(p, q)$ processes of serial correlation and hetroskedasticity in testing the regression. Consider the following equation:

$$
\mathrm{Yt}=\mu_{0}+\mu_{1} \mathrm{yt}_{-1}+\mu_{2}(\mathrm{t}-\mathrm{T} / 2)+\varepsilon \mathrm{t}
$$

Where $\mathrm{T}$ is the number of observation and $\mathrm{st}$ is the error term. The null hypothesis of a unit root is $\mu 1=1$. Since most macroeconomic variables are found to be non-stationary and show trending over time [14], difference or de trend the variables is important in order make them stationary. In the case where the variables are difference stationary, it is possible to estimate the model by first difference. However, this gives only the short run dynamics in which case valuable information concerning the long equilibrium properties of the data could be lost [46].

In this study, an econometric model for industrial output growth is established as follows:

$$
\text { INGDP }=\mathrm{f} \text { [lagged INF, CF, ILR, MS, REER, TB] }
$$

Where INGDP, INF, CF, LR, MS, REER and TB stands for industrial output, inflation rate, capital formation (investment), lending rate, money supply, real effective exchange rate and trade balance, respectively. The multiple regression equation models to explore the macroeconomic factors that influence industrial output growth in Ethiopia is stated as:

$$
\begin{gathered}
\operatorname{lnINGDP}{ }_{\mathrm{t}}=\beta_{0}+\beta_{1}(\text { INF })_{\mathrm{t}}+\beta_{2}(\operatorname{lnCF})_{\mathrm{t}}+\beta_{3}(\mathrm{LR})_{\mathrm{t}}+ \\
\beta_{4}(\operatorname{lnMS})_{\mathrm{t}}+\beta_{5}(\operatorname{lnREER})+\beta_{6}(\mathrm{~TB})_{\mathrm{t}}+\varepsilon_{\mathrm{i}}
\end{gathered}
$$

Where $\ln L N G D P_{t}$ is the natural $\log$ of industrial output, $I N F_{t}$ is inflation rate, $\ln C F_{t}$ is the natural $\log$ of capital formation (investment), $L R_{t}$ is lending rate, $\ln M S_{t}$ is natural $\log$ of broad money supply, $\ln R E E R_{t}$ is the natural $\log$ of real effective exchange rate and $T B_{t}$ is the natural log of trade balance, and $\varepsilon_{i}$ is the stochastic error term. The above function describes the relationship that is to be analyzed, i.e. how the industrial output growth, to the left, is affected by the factors to the right.

\subsubsection{Co-integration Analysis}

The autoregressive distributed lag model (ARDL)

The ARDL testing instrument which was developed by [36], tests for the existence of a co-integration relationship among the independent variables that can be applied regardless of whether the targeted variables are a combination of stationary series at a level and at first difference. This approach reconstructs the ARDL model through overcoming the problems associated with the presence of a combination of stationary variables at different level which are not possible in Engle and Granger and the Johansen approaches. This approach also reduces serial correlations and endogeneity problems and provides unbiased estimates of the long run and short run model and valid tstatistics $([11,19])$.

The above equation (4) are re-arranged into Autoregressive Distributed Lag model (ARDL) form to estimate both short-run and long- run relations and error correction term (ECT), which is derived from long run relation. The resulting new equations (5) became as follows.

$$
\begin{array}{r}
D(\ln (I N G D P))=\beta 0+\beta 1 \ln (I N G D P t-i)+ \\
\beta 2 \ln (I N F t-i)+\beta 3 \ln (C F t-i)+\beta 4 \ln (L R t-i)+ \\
\beta 5 \ln (M S t-i)+\beta 6 \ln (R E E R t-i)+\beta 6(T B t-i)+ \\
\sum_{i=1}^{p} \alpha 1 D(\ln (I N G D P t-i))+\sum_{i=1}^{p} \alpha 2 D(\ln (I N F t-i))+ \\
\sum_{i=1}^{p} \alpha 3 D(\ln (C F t-i))+\sum_{i=1}^{p} \alpha 4 D(\ln (L R t-i))+ \\
\sum_{i=1}^{p} \alpha 5 D(\ln (M S t-i))+\sum_{i=1}^{p} \alpha 6 D(\ln (R E E R t-i))+ \\
\sum_{i=1}^{p} \alpha 7 D(T B t-i)+\varepsilon t
\end{array}
$$

Where in the equations above, all the variables are already defined previously, $I n$ denotes logarithmic operator, $D$ is difference of a variable and $\varepsilon_{t}$ are error terms. $i$ is the 
maximum lag number, $\beta_{1}-\beta_{6}$ represent long-run coefficients of explanatory variables, $\alpha_{1}-\alpha_{7}$ represent short-run coefficients of explanatory variables. The F-statistic is carried out on the joint null hypothesis that the coefficients of the lagged variables is equal to zero $\left(\beta_{1}=\beta_{2}=\beta_{3}=\beta_{4}=\beta_{5}=\right.$ $\left.\beta_{6}=0\right)$ and alternative hypothesis $\beta_{1} \neq \beta_{2} \neq \beta_{3} \neq \beta_{4} \neq \beta_{5} \neq \beta_{6}$ $\neq 0$, to test long-run relationship of the model. Then the ARDL technique provides a unified framework for testing and estimating of co-integration relations in the context of a single equation.

ARDL Bounds test for co-integration has two sets of critical values which are called upper and lower critical bound for co-integration test. The lower bound assumes that all the regresses are I (0) i.e. at level, and the upper bound assumes that they are I (1) i.e. at first level. Then, the ARDL bound test has these three possible decision rules.

Rule1: if the F-statistics lied above the upper bound of the critical value for a given significance level, the study will fail to accept the null hypotheses of no co-integration.

Rule2: if the F-statistics lied below the lower bound of the critical value for a given significance level, the study will fail to reject the null hypotheses of no integration.

Rule3: if the F-statistics lied in between the lower and the upper bound of the critical value for a given significance level, then the decision will be indifference. The study will neither accept nor reject the null hypotheses. ECM representing the error correction term is derived from the long-run co-integrating relation from the specified ARDL model. ECT should exhibit a negative and significant sign for causality to exist in the long run. [10] demonstrated that causal relations among variables can be examined within the framework of ECM, with co-integrated variables.

$$
D(\ln (L N G D P)) t=\beta 0+\sum_{i=1}^{p} \beta 1 D(\ln (L N G D P t-i))+\sum_{i=1}^{p} \beta 2 D(X t-i)+E C T t-1+\mu t
$$

The coefficient of error correction term (ECT) contains the information about long-run causality if it is a negative and statistical significant, then ECT is assumed to signify long run causality. Once the error correction models have been estimated, the cumulative sum of recursive residuals (CUSUM) and the CUSUM of square (CUSUMSQ) tests used to assess the parameter constancy stability.

\subsubsection{Definition of Variables and Priori Expectation}

The industrial sector of Ethiopia, according to MoFEC classification, comprises; large and medium scale manufacturing, small scale industry and handicrafts, electricity and water, mining and quarrying and, construction subsectors. It is taken as a natural $\log$ of industrial output ( $\ln \mathrm{INGDP})$.

Inflation rate: Inflation is defined as a sustained increase in the general level of prices for goods and services. It is measured as an annual percentage increase. Inflation rate as measured by the general price level is expected to have a negative impact on industrial output growth. Investment on industry can be influenced by the price of industrial inputs and the price industrial products (hence industrial output market) also have a convincible impact on its own demand.

Real effective exchange rate (REER): The data for REER is found from national bank of Ethiopia and based on IMF definition of exchange rate description (foreign currency to domestic currency/USD to ETB). A higher real effective exchange rate (depreciation of domestic currency), makes domestic products (exportable) cheap and imported products expensive as a result domestic firms are encouraged to produce and sell more industrial products.

Lending rate: A rate which is charged or paid for the use of money. Higher lending rate discourages private investment and hence results less industrial output growth.

Money supply: increasing money supply might lead to lower interest rate and consequently encourages investment on one hand, or it may leads to inflationary pressure as more money is provided on people's hand. So money supply may go for or against to industrial output growth. Capital formation: Any expenditure in the form of capital formation would not go against industrial output growth.

Trade Balance: it is computed as the total value of exports less the total value imports in a given period of time. Since higher trade balance signifies more import than export it discourages domestic and exposes firms to adverse competition consequently it would have a negative impact on industrial output growth.

\section{Discussion and Analysis}

\subsection{An Overview of Ethiopian Industrial Sector}

\subsubsection{Sectoral Output and Economic Growth}

One of the characteristic features of the Ethiopian economy is it is largely dominated by agricultural sector. The sector is the leading in terms of; contribution to the national output, being a major source of foreign currency earning and employment creation. As 'figure 1' below show, from 1991 up to 2011 agricultural sector was the leading in terms of composition of the total GDP. Starting from 2011, the service sector surpassed the agricultural sector leaving the industrial sector stagnating over the study years. This unsuccessful transition from agriculture to service sector is not in the conventional path and results a premature industrialization. According to [30], the experience of some other countries shows the economic development follows a sequence where tertiary sector developed without creating an industrialized economy. And this is hazardous drive for agrarian economies, like Ethiopia.

This low performance of industrial sector is one of the characteristic features of most African countries. According to [21], the share of manufacturing sector to GDP of Ethiopia is found to be low, compared with most African countries.

\subsubsection{Industry Sector}

The current government of Ethiopia has given especial 
attention for the development of industrial sector. The past and the current national economic plans such as GTPI and GTPII incorporated considerable targets although their achievement questionable.

According to Ministry of Economic Development and Cooperation (MoFEC) of Ethiopia classification, industry sector has five major sub-sectors; large and medium scale manufacturing, small scale industry and handicrafts, electricity and water, mining and quarrying and, construction. The construction sub sector is largest among industry components. Different constructions such as; road, railway, dams and irrigations, real-estate and condominium have been expanding in the realm of growing demand for these constructions.

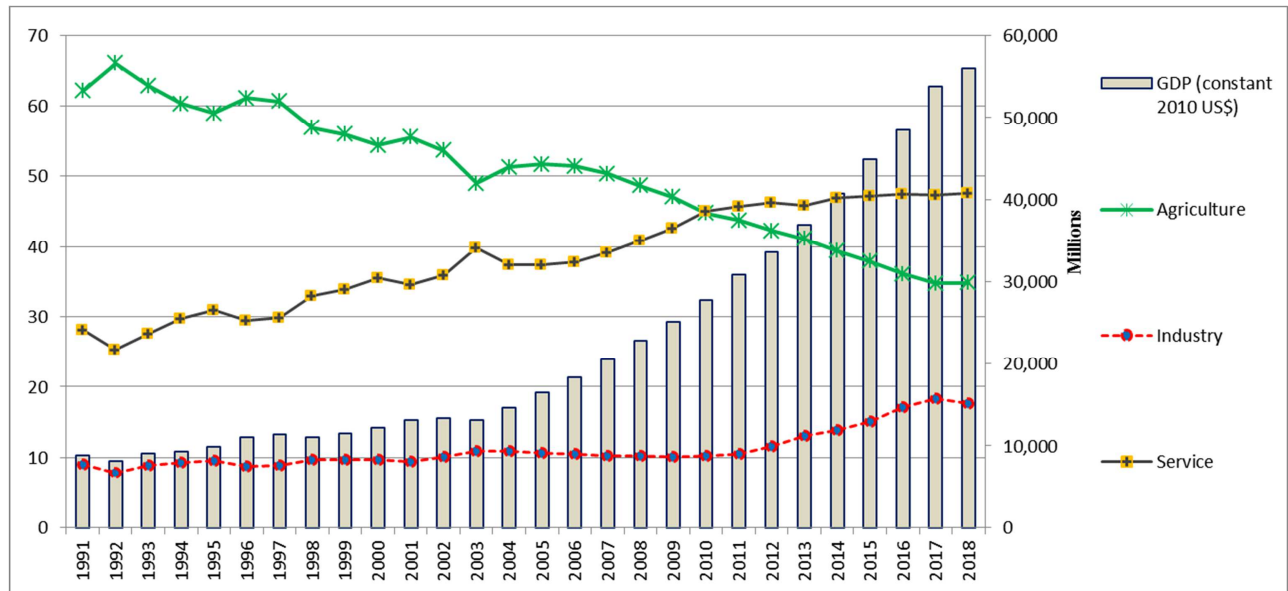

Source: authors' computation.

Figure 1. Sectoral output and economic growth.

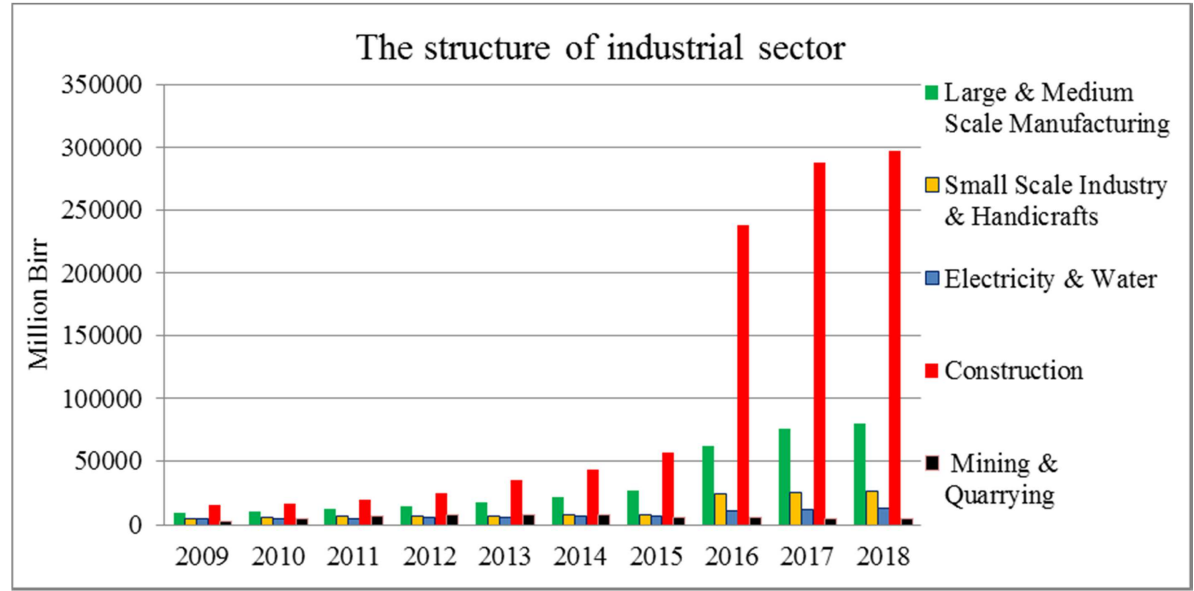

Source: authors' computation.

Figure 2. The structure of industrial sector.

Compared to the rest of sectors, the percentage share of industrial output to GDP is very low. 'Table 1' shows the five year average Industrial sector value added, growth rate and percentage share of GDP. Accordingly, the growth rate of industrial output was high between 2009 and 2013 and; in terms of percentage share of GDP the highest value observed between 2014 and 2018 which was 16.6 percent. This is because, the government of Ethiopia gives special emphasis for the development of industrial sector, particularly through GTP I \& II national plans.

Table 1. Industry sector value added, growth rate and percentage share of GDP.

\begin{tabular}{llll}
\hline \multirow{2}{*}{ Interval } & Industry & & \\
\cline { 2 - 4 } & Value added (million) & Growth rate & Share to GDP \\
\hline $1991-1998$ & 884380417.7 & 0.050 & 9.0 \\
$1999-2003$ & 1263638540 & 0.061 & 10 \\
$2004-2008$ & 1941480989 & 0.101 & 10.47 \\
$2009-2013$ & 3466010519 & 0.158 & 11.24 \\
$2014-2018$ & 8086403665 & 0.156 & 16.6 \\
\hline
\end{tabular}

Source: authors' computation. 
The Ethiopian economy is mainly characterized by the predominance of agricultural sector. The sector is main the source for foreign currency, employment and contribution to GDP. Agricultural sector covered more than 65 percent (as of 2018) of total employment whereas; the industrial sector covers less than ten percent of total employment created by the economy, over the study year.
'Figure 3' depicts the agricultural, service and industrial sectors are the first, second and third in terms of share of total employment. However, the employment levels of industrial and service sectors are increasing while the agriculture is declining. This could be due to the subtle underpinning of structural change in the economy; the movement of workers from rural to urban sectors.

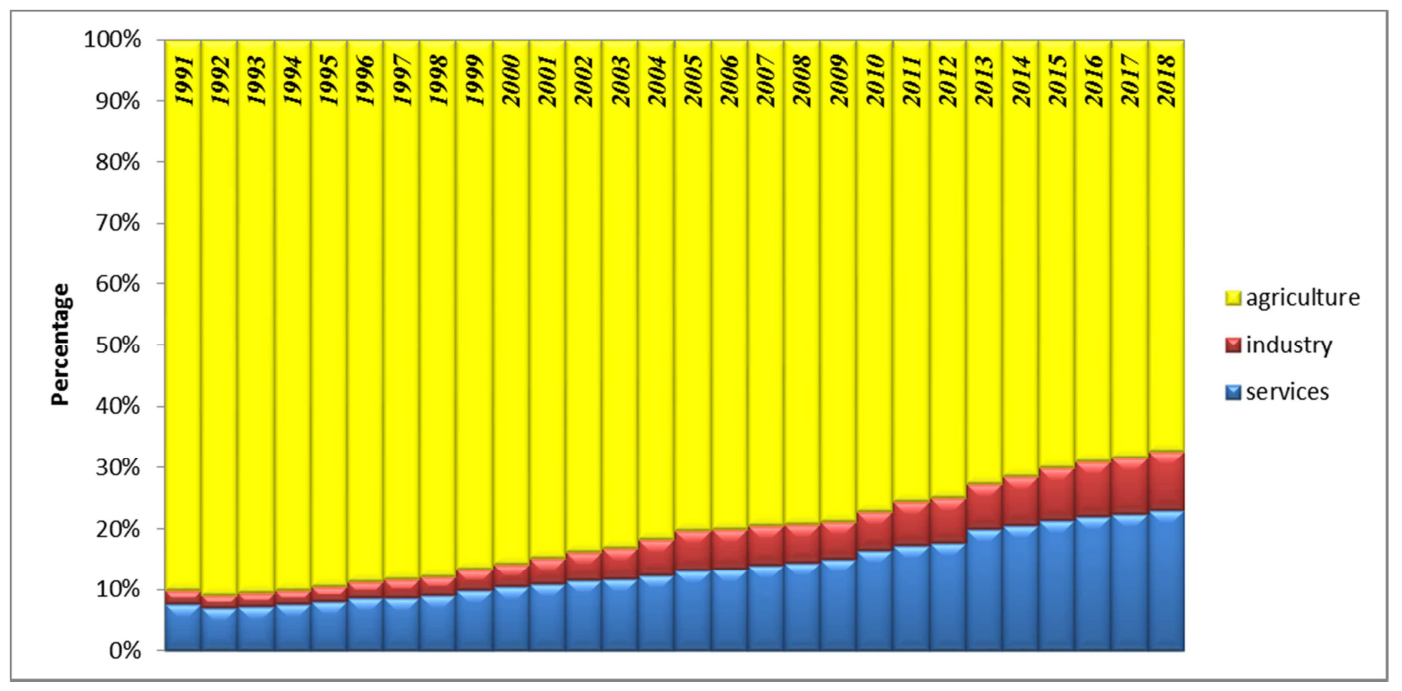

Source: authors' computation.

Figure 3. Sectoral Employment as a percentage of total labour force.

\section{Labor productivity of the industrial sector}

The term "productivity" can be simply referred to as the relationship between production of output and the inputs of production such as; labour, land, capital and technology, used in achieving the given job. It is measured as a ratio of output per unit of input over time and is often used a measure of efficiency [8]. Likewise labour productivity measures the amount of output per unit of labour. Ethiopia as one of the least developed countries, it has very limited capital but abundant labor force and hence its industries are predominantly labor intensive instead of capital intensive. For this reason labor productivity becomes appropriate for measuring performance of the industrial sectors. In this study, labor productivity is measured by the real value added production per engaged person in the industrial sector.

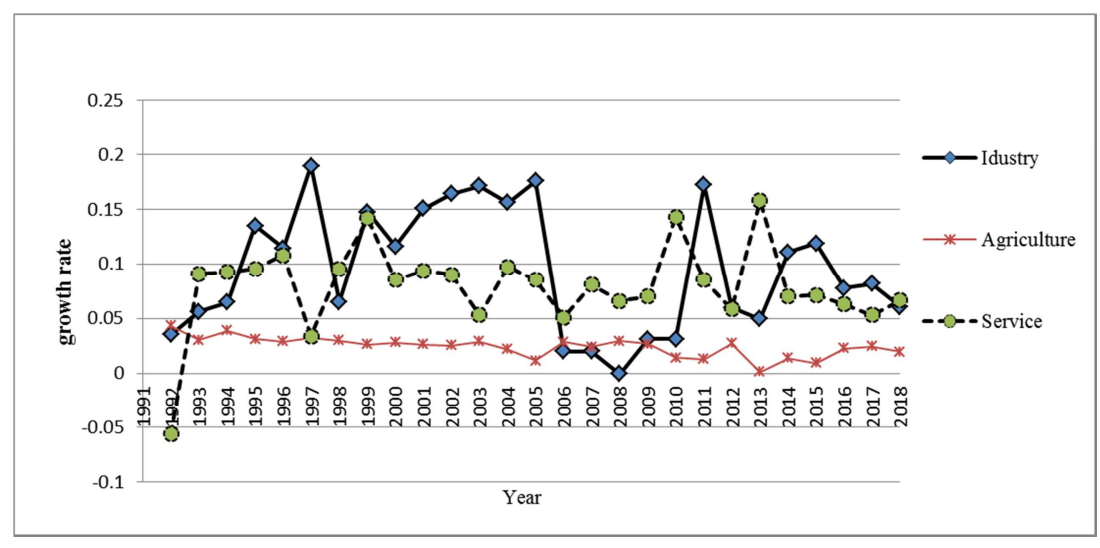

Source: authors' computation.

Figure 4. Sectoral labour productivity growth rates.

As is shown in 'figure 4' above, the growth rate of labour productivity of the industrial sector has been fluctuating. One interesting thing here is that the growth rate of service and industrial sectors seem offsetting each other; when one increase /decrease, the other decrease/increase. This could be accrued to the movement of workers between the two sectors; with ceteris - paribus the sector that recruits more workers would have a lower labour productivity and the sector that fires workers would have higher labour productivity. The prevailing lower market wage rate initiates these two sectors to 
compute for the existing jobs. On the other hand the labour productivity growth rate of agricultural sector is in somehow low over the study year. Since the sector is not mechanized and the modern sectors are virtually undeveloped to attract workers from the traditional sector, such low labour productivity growth rate cannot be surprising.

\subsection{Regression Analysis}

\subsubsection{Unit Root Test}

In time series analysis with econometrics results, before running any test it is important to distinguish between correlation that arises from a share trend and one associated with an underlying causal relationship. Regression of nonstationary time series will lead to spurious estimates. Unit Root tests deal with the situation where estimation result claim statistical significance of the long run relation between variables in a given regression analysis just because of trending relations among these variables than presence of true momentous casual relations.

Augmented Dickey-Fuller (ADF) test and Phillips Perron (PP) unit root tests are employed to check for Unit Root or Non-Stationary of the variables and applied differencing.

Table 2. Unit root test results of ADF and PP test at level I (0).

\begin{tabular}{lllll}
\hline \multirow{2}{*}{ Variables } & \multicolumn{2}{l}{ ADF test at level I (0) } & \multicolumn{2}{l}{ PP test at level I (0) } \\
\cline { 2 - 5 } & t-Statistic & P value & t- stat & P value \\
\hline $\operatorname{lnINGDP}_{\mathrm{t}}$ & 3.720736 & 1.0000 & -1.059653 & 0.9176 \\
$\operatorname{lnINF}_{\mathrm{t}}$ & $-3.933593^{* *}$ & 0.0244 & $-3.925805^{* *}$ & 0.0248 \\
$\operatorname{lnCF}_{\mathrm{t}}$ & -1.271953 & 0.8734 & -1.271953 & 0.8734 \\
$\operatorname{lnINR}_{\mathrm{t}}$ & -1.870503 & 0.6382 & $-3.571399 * * *$ & 0.0551 \\
$\operatorname{lnREER}_{\mathrm{t}}$ & -2.611794 & 0.2783 & $-5.601296 *$ & 0.0005 \\
$\operatorname{lnTB}_{\mathrm{t}}$ & 0.210481 & 0.9968 & 0.244396 & 0.9971 \\
$\operatorname{lnMS}_{\mathrm{t}}$ & 0.449800 & 0.9985 & 0.115515 & 0.9958 \\
\hline
\end{tabular}

$* * *$ and $* * *$ represents significance level at $1 \%, 5 \%$ and $10 \%$ critical values, respectively.
Table 3. Unit root test results of ADF and PP test at level I (1).

\begin{tabular}{lllll}
\hline \multirow{2}{*}{ Variables } & \multicolumn{2}{c}{ ADF test at I (1) } & \multicolumn{2}{l}{ PP test at level I (1) } \\
\cline { 2 - 5 } & t-Statistic & P value & t- stat & P value \\
\hline $\operatorname{lnINGDP}$ & -4.475080 & 0.0080 & $-5.085448^{*}$ & 0.0019 \\
$\mathrm{INF}_{\mathrm{t}}$ & $-7.014833^{*}$ & $0.0000^{*}$ & $-11.04300^{*}$ & 0.0000 \\
$\operatorname{lnCF}_{\mathrm{t}}$ & -3.578643 & 0.0534 & -6.417619 & 0.0001 \\
$\mathrm{INR}_{\mathrm{t}}$ & $-3.571399^{* * *}$ & 0.0551 & $-5.633609 *$ & 0.0005 \\
$\operatorname{lnREER}_{\mathrm{t}}$ & $-4.847221^{*}$ & 0.0035 & $-5.473306^{*}$ & 0.0008 \\
$\mathrm{~TB}_{\mathrm{t}}$ & -4.055578 & 0.0198 & -4.270781 & 0.0121 \\
$\operatorname{lnMS}_{\mathrm{t}}$ & -3.286804 & 0.0906 & -3.261828 & 0.0949 \\
\hline
\end{tabular}

$* * *$ and $* * *$ represents significance level at $1 \%, 5 \%$ and $10 \%$ critical values, respectively.

As shown from 'tables 2 and 3', variables $\ln$ INFt is found to be stationary at level ( 0 ) using both the Augmented Dickey Fuller (ADF) and Phillips Perron (PP) unit root test. There for the null hypotheses for these variables are failed to be accepted. Based on Phillips Perron (PP) unit root test result, $\ln \mathrm{REER}_{\mathrm{t}}$ also found to be stationary at level $(0)$. For the remaining variables a first difference of them is taken to test their stationarity. As the result of the first difference test depicted in the table aboves, variables $\ln \mathrm{INGDP}_{\mathrm{t}}, \ln \mathrm{INF}_{\mathrm{t}}$, $\ln \mathrm{CF}_{\mathrm{t}}, \ln \mathrm{INR}_{\mathrm{t}} \ln \mathrm{MS}_{\mathrm{t}}$ and $\ln \mathrm{TB}_{\mathrm{t}}$ become stationary at their first difference of the ADF and PP tests. Therefore the null hypotheses for these variables are also failed to be accepted.

\subsubsection{Bound Test of Co-integration}

Once the series are tested for stationary, the next step is testing for the existence of long run relationship. We employed ARDL model through bounds test to identify the presence of the long run relationship among all the series. If the F-statistics lied above the upper bound of the critical value for a given significance level, the study will fail to accept the null hypotheses of no co-integration. The result of the bounds tests is reported in 'table 4'.

Table 4. Long run ARDL bounds tests Null Hypothesis: No long-run relationships exist.

\begin{tabular}{lllll}
\hline Model & F-Statistics & Significance level & Lower bound & Upper bound \\
\hline \multirow{3}{*}{ Industry } & & $10 \%$ & 1.99 & 2.94 \\
& $7.396643^{*}$ & $5 \%$ & 2.27 & 3.28 \\
& & $1 \%$ & 2.88 & 3.99 \\
\hline
\end{tabular}

Source: Author's calculation from E view 10 results, 2018.

Notes: ARDL Models selected on Akaike info criterion (AIC) automatically, intercept and no trend for k- 6 ; the sign of * indicate the level of significance at $1 \%$ to reject the null hypothesis of No long-run relationships exist respectively.

The order of the variables is industrial output, inflation rate, interest rate, trade balance, capital formation (investment), broad money supply and real effective exchange rate. The value of F-Statistics (7.396643) is much greater than the upper bound value of $1 \%, 5 \%$ and $10 \%$ significance level. Therefore we can conclude that there is a long-run relationship between explained and explanatory variables, when industrial output is modeled as dependent variable.

\subsubsection{Long Run Equation}

Since we have specified the growth model in a log-log form except for inflation rate, trade balance and lending rate, the coefficients can be interpreted as elasticity with respect to agricultural output. However trades balance (Export valueimport value) is negative for most periods under consideration; therefore its value is a non-positive number. But interest rate and inflation rates are already given as percentage. 
Table 5. Long run Coefficients.

\begin{tabular}{|c|c|c|c|c|}
\hline \multicolumn{5}{|c|}{ Dependent Variable: LNIND } \\
\hline \multicolumn{5}{|c|}{ Selected Model: ARDL $(2,1,2,2,2,2,2)$} \\
\hline Variable & Coefficient & Std. Error & t-Statistic & Prob. \\
\hline $\mathrm{C}$ & 7.779714 & 3.007385 & 2.586870 & $0.0414 * *$ \\
\hline LENDING_RATE & -0.048610 & 0.020166 & -2.410494 & $0.0525^{* * *}$ \\
\hline INFLATION & 0.010783 & 0.005175 & 2.083656 & $0.0823 * * *$ \\
\hline LNCAP & 0.168025 & 0.424333 & 0.395974 & 0.7058 \\
\hline LNMONEY & 0.081572 & 0.230835 & 0.353378 & 0.7359 \\
\hline REER & 0.000404 & 0.002578 & 0.156505 & 0.8808 \\
\hline TB & -0.000010 & 0.000002 & -4.116114 & $0.0062 *$ \\
\hline
\end{tabular}

Source: Author's calculation from E view 10 results, 2018.

Note: The sign * and *** indicate that the variables are significant at the level of $1 \%$ and $10 \%$ respectively.

From the long-run coefficients except for the lending rate (interest rate) rate and trade balance all other independent variables affect the industrial output growth positively. The level of inflation rate, capital formation, money supply and real effective exchange rate affects industrial sector output growth positively. However the effect of capital formation, money supply and real effective exchange rate on industrial output growth is insignificant, meaning in the long run these variables have no significant effect on industrial sector output growth.

When the inflation rate increases by one percent, industrial output will increase by about 0.01 percent, at citrus paribus. Showing that, any increase in inflationary rate would increase the output of the industrial sector in Ethiopia. This result is justified in that firms tend to produce more during inflationary periods that are characterized by high price final products which further encourages the $m$ to produce more.

When, trade balance (export value less import value) increase by one percent the growth rate of industrial output declines by about -0.00001 percent. Therefore trade balance has a negative effect on industrial output growth. The possible explanation for effect is that unlimited importation of goods and services discourages domestic firms. Since domestic firms are not capable to compute with international produces, unrestricted importation could harm them. Therefore as the theory of infant industry argued, protecting infant industries from superior competitors provides domestic markets and ultimately this leads the infant producers to enjoy scale economies [7].

Similarly, when the lending rate (as a proxy of interest rate for borrowers) increases by one percent, the growth rate of industrial output declines approximately by 0.048 percent. Higher interest rate my prohibit firms not to start or expand their business. This result is consistent with [32, 42] study whose study found that lending rate has a significant effect on manufacturing sector.

\subsubsection{Short Run Equation}

In the short run the most important short-run determinants of industrial output growth in Ethiopia are found to be a oneyear lagged value of industrial output, trade balance, capital formation (investment) and money supply.

Table 6. Short-run coefficients for agricultural output growth.

\begin{tabular}{|c|c|c|c|c|}
\hline \multicolumn{5}{|l|}{ Co-integrating Form } \\
\hline Variable & Coefficient & Std. Error & t-Statistic & Prob. \\
\hline D (LNIND (-1)) & -0.468415 & 0.115534 & -4.054335 & $0.0067^{*}$ \\
\hline D (LENDING_RATE) & -0.031159 & 0.016080 & -1.937691 & 0.1008 \\
\hline D (INFLATION) & 0.003607 & 0.001509 & 2.391415 & $0.0539 * * *$ \\
\hline D (INFLATION (-1)) & -0.004005 & 0.001979 & -2.023658 & $0.0894 * * *$ \\
\hline D (LNCAP) & 0.649185 & 0.147251 & 4.408687 & $0.0045^{*}$ \\
\hline D (LNCAP (-1)) & 0.406735 & 0.181363 & 2.242660 & $0.0661 * * *$ \\
\hline D (LNMONEY) & -0.528436 & 0.268993 & -1.964500 & $0.0971 * * *$ \\
\hline D (LNMONEY (-1)) & -0.329752 & 0.346822 & -0.950782 & 0.3784 \\
\hline D (REER) & 0.004179 & 0.002476 & 1.687565 & 0.1425 \\
\hline D (REER (-1)) & 0.000640 & 0.000736 & 0.869143 & 0.4182 \\
\hline $\mathrm{D}(\mathrm{TB})$ & 0.000005 & 0.000001 & 4.145678 & $0.0060^{*}$ \\
\hline D (TB (-1)) & 0.000005 & 0.000003 & 1.510567 & 0.1816 \\
\hline $\operatorname{ECT~}(-1)$ & -0.833648 & 0.258963 & -3.219175 & $0.0182 * *$ \\
\hline
\end{tabular}

Cointeq $=$ LNIND $-(-0.0486 *$ R LENDING RATE $+0.0108 *$ INFLATIONWB $+0.1680 *$ LNCAP $+0.0816 *$ LNMONEY $+0.0004 *$ REER $-0.0000 *$ TB +7.7797$)$.

Source: Author's calculation from E view 10 results, 2018.

Note: The sign * and ** indicate that the variables are significant at the level of $1 \%$ and $5 \%$ respectively.

The coefficient of previous output of industrial output showed a significant negative influence on industrial output. 
The expansion of industrial sector is sensitive for its own past performances. Lending rate exhibited a negative relationship with industrial output in Ethiopia. This means that lending rate has the potential of shrinking industrial output growth in Ethiopia. At a higher lending rate firms tend to be refraining themselves from lending money and investing on industry sector. In the short an increase in trade balance (large amount of import relative to export) may stimulate production of industrial products, since industrial products relied on imported technologies. Capital formation as expected has a positive and significant effect on industrial output growth. The government of Ethiopia gives special attention for the development of this sector; hence transferring of productive resources toward industry is beneficial for the sector.

The error correction term shows how much of the disequilibrium is being corrected, that is, the extent to which any disequilibrium in the previous period is being adjusted. A negative of coefficient ect-1 indicates a convergence back to long run equilibrium; while a positive coefficient of ect-1 indicates a divergence. From 'table 6' the value of the lagged error correction term (ect) is significant at $1 \%$ level with the expected negative sign with the estimated coefficient value -
0.83 , which implies the speed of adjustment to long run equilibrium is very high. The coefficient of error correction term also suggests that about 83 percent of long-run disequilibrium is adjusted from lagged period error shocks. The significance of the error correction mechanism (ECM) supports co-integration and suggests the existence of a longrun steady-state equilibrium relationship between industrial output growth and explanatory variables.

\subsubsection{Model Diagnostic Test}

In order to analyze validity of the short-run and long-run estimation in the ARDL model, the diagnostic tests are the mandatory. Different diagnostic test such as Serial correlation test (Brush \&Godfray LM test), Heteroscedasticity test (Brush and Godfray LM test), Normality (Jaque-Bera test) and Functional form (Ramseys RESET) test were performed. The tests and their respective statistics are summarized by 'table 7' below. In order to test for normality of the residual the study used the popular Jarque-Beranormality test. The hypothesis that is going to be tasted are,

$H_{0}$ : residuals are normally distributed and,

$H_{\alpha}$ : residuals are not normally distributed.

Table 7. Long run ARDL Diagnostic Tests for industrial output growth.

\begin{tabular}{|c|c|c|c|c|}
\hline \multirow{2}{*}{ Tests } & \multicolumn{2}{|l|}{ LM-version } & \multicolumn{2}{|l|}{ F-version } \\
\hline & Statistic & P-value & Statistics & P-value \\
\hline Normality: Jarque-Bera test & $X^{2}(2)=4.084721$ & 0.12972 & Not applicable & \\
\hline Serial Correlation: Breusch-Godfrey serial correlation LM test & $X^{2}(2)=6.901445$ & 0.0317 & $F(2,4)=0.72271$ & 0.5396 \\
\hline Heteroskedasticity: Breusch-Godfrey test & $X^{2}(19)=12.87682$ & 0.8448 & $F(19,6)=0.309861$ & 0.9767 \\
\hline
\end{tabular}

Source: Author's calculation from E view 10 results, 2018.

If $\mathrm{P}$-value of Jarque-Bera test is greater than 5\% we accept the null hypothesis but if P-value is below 5\% we reject the null hypothesis. As demonstrated in 'table 7' above, the P-value of the Jarque-Bera Normality test is greater than 5\%. Therefore, the study failed to reject the null hypothesis and conclude that error terms of the specified model are normally distributed.

To test heteroscedasticity this study used Breusch-paganGodfrey test because these test is used in most studies using ARDL model. The decision rule for this test for heteroscedasticity states that, if the p-value of the BreushPagan-Godfrey test is greater than 5\% it indicates no possible problem of heteroscedasticity. Accordingly the p-values of the equations are above the critical value (5\%), implying that the residuals of the equations have no problem of heteroscedasticity. Under Breusch-Godfrey serial correlation test, if $\mathrm{P}$-value is above 5\% accept the null hypothesis which states there is no serial correlation between residuals. In the other case if $\mathrm{p}$ - value is below $5 \%$ we reject the null hypothesis and accept the alternative hypothesis which states there is serial correlation. Following the result shown in the table above, for the model specified their p-value is greater than $5 \%$ which assures that there is no serial correlation problem and the study accepts the null hypothesis, therefore there is no serial correlation between residuals under this study.

Stability Test

To examine stability of long-run parameters, this study relied on cumulative sum (CUSUM) and cumulative sum square (CUSUMSQ) test. This procedure was also utilized by [35] to test the stability of long-run coefficients. For CUSUM test, the null hypothesis states the regression equation is correctly specified and the alternative hypothesis states the regression equation is not correctly specified. The null hypothesis cannot be rejected if the plot of these statistics remains within the critical bounds of 5\% significance level.

The 'figure 5' shows the plot of both CUSUM and CUSUMSQ statistics of the model. As it can be seen from the figures, the plots of CUSUM and CUSUM square for the equation stays within the critical $5 \%$ boundaries. This confirms the long-run relationship among variables and the study accepts the null hypothesis and concludes that there is stability for the long-run coefficients of regressors under the model specified. 

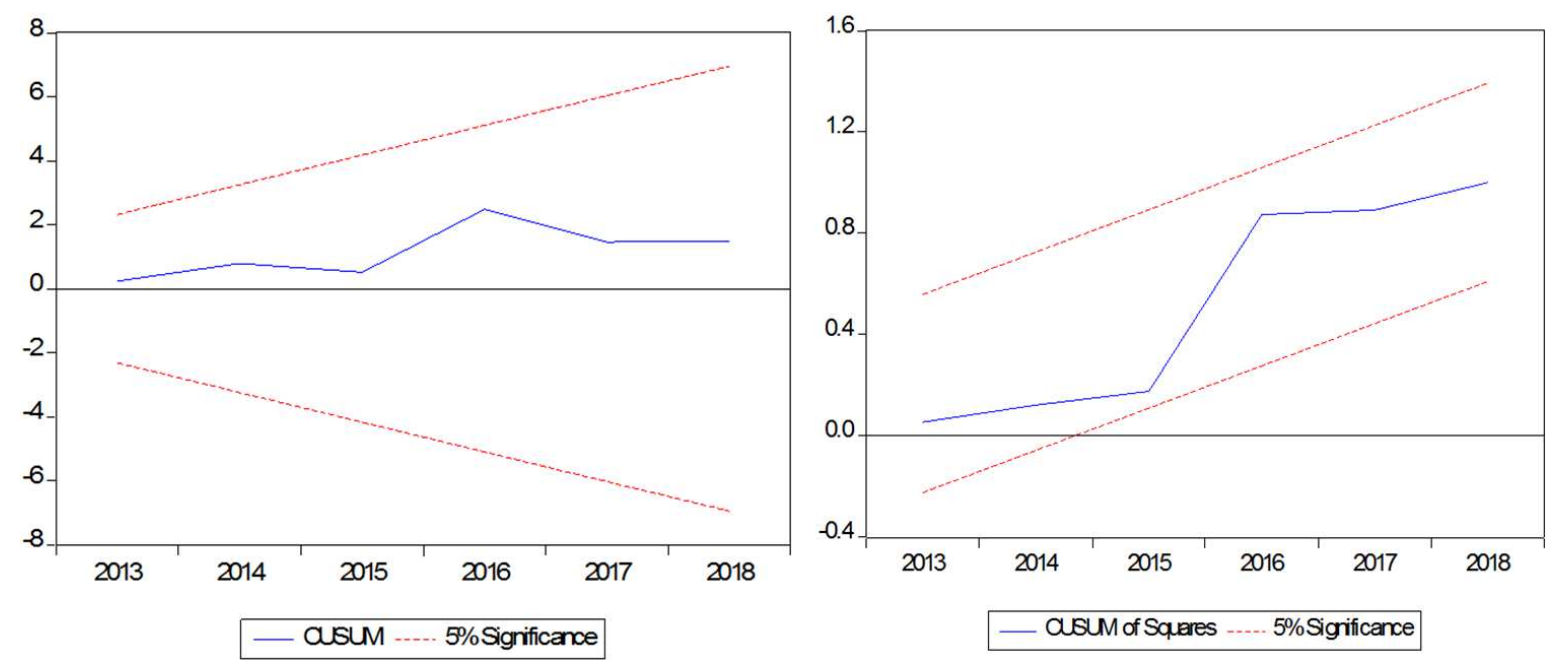

Source: EViews 10 result.

Figure 5. Plot of CUSUM and CUSUMSQ test.

\section{Conclusion and Policy Recommendation}

This study examined the effect of some macro-economic variables such as, inflation rate, capital formation, interest rate, money supply, real effective exchange rate and trade balance on industrial output growth of Ethiopia. The Stationary test confirmed that the variables under consideration are found to be stationary at level and first difference hence all variable are mixed which is suitable for ARDL estimation. The ARDL bound test cointegration confirmed the existence ofa long run meaningful relationship between industrial output growth and macroeconomic variables, when industrial output growth modeled as dependent variable.

In the long-run the level of inflation rate, capital formation, money supply and real effective exchange rate affects industrial sector output growth positively. However the effect of capital formation, money supply and real effective exchange rate on industrial output growth is insignificant, meaning in the long run these variables have no significant effect on industrial sector output growth. The inflation rate is found to be having a positive and significant effect on industrial outputgrowth which is oppositeto our priori expectation. Showing that, any increase in inflationary rate would increase the output of the industrial sector in Ethiopia. This result is justified in that firms tend to produce more during inflationary periods that are characterized by high price final products which further encourage them to produce more.

Trade balance affects industrial output growth negatively and statistically significantly. The possible explanation for negative impact is that unlimited importation of goods and services discourages domestic firms. Since domestic firms are not capable to compute with international produces, unrestricted importation could harm them. However In the short an increase in trade balance (large amount of import relative to export) may stimulate production of industrial products, since industrial products relied on imported technologies.

Lending rate as priori expected affects industrial output growth negatively and significantly both in the long run and short run. Higher lending rate (interest rate for borrowers) could prohibit firms not to start or expand their business. This means that lending rate has the potential of shrinking industrial output growth in Ethiopia. At a higher lending rate firms tend to be refraining themselves from lending money and investing on industry sector.

In the short run capital formation as expected has a positive and significant effect on industrial output growth but not in the long run. The coefficient of previous output of industrial output showed a significant negative influence on industrial output. The expansion of industrial sector is sensitive for its own past performances. In addition money supply found also to be is having negative impact on industrial sector output growth in the short run. The lagged error correction term (ect) is significant at $1 \%$ level with the expected negative sign with the estimated coefficient value -0.83 . The coefficient of error correction term suggests that about 83 percent of long-run disequilibrium is adjusted from lagged period error shocks. Based on the result the following policy implications are forwarded;

Lending rate: from the study lending rate (interest rate) is identified as a major determinant of industrial sector output growth in Ethiopia both in short-run and long-run. Since higher interest rate is a disadvantageous for private investors, the government should maintain it to the level that could be amenable for firms.

Trade balance (LR): trade balance is found to have a negative effect on industrial sector output growth both in long-run and short run. Unfavorabletrade balance is common economic phenomenon for most of developing countries. Most developing countries exports primary and unprocessed 
products and import manufactured and processed products. Since primary products are price and income inelastic and its price determined by developed countries, it is becoming the major reason for the unfavorable trade balance.

Hence the government of Ethiopia needs to balance its import and export. Unrestricted importation of manufactured goods exposes domestic firms to undesirable competition with international producers and this will ultimately drive them out from domestic markets. Therefore protecting domestic industries/producers from superior competitors provides domestic markets.

Any attempt made by government towards exchange rate should take in to account its relevance to the growth of industrial sector since; real effective exchange rate has insignificant effect on industrial output growth.

\section{References}

[1] Adegbemi, B. (2018). Macroeconomic Dynamics and the Manufacturing Output in Nigeria. Department of Economics, Babcock University, Ilishan - Remo, Nigeria. Mediterranean Journal of Social Sciences Vol 9 No 2, Pp 43-54.

[2] Adisu A. (2018). A causality analysis of intersectoral linkages in Ethiopian economy. Wollega University, Nekemte, Ethiopia.

[3] Bassey, N., Asinya,. F, Amba, E.(2014). Bank Credit Finance and Macro Economic Determinants of Industrial Output in Nigeria 1980-2010. International Journal of Humanities and Social Science Vol. 4, No. 6; April 2014.

[4] Beji S., Belhadj A.(2017) The Determinants Of Industrialization: Empirical Evidence For Africa European Scientific Journal. /SPECIAL/ edition ISSN: 1857-7881 (Print) e - ISSN 1857-7431.

[5] Bolnick, B. (1991). Weak links in the monetary transmission mechanism: The case of Malawi, ODI/HIID Conference on Improving Monetary Policy in Africa and Asia, unpubished manuscript.

[6] Bruno M., Marco S., Nobuya H. (2017) What factors drive successful industrialization? Evidence and implications for developing countries. DEPARTMENT OF POLICY, RESEARCH AND STATISTICS WORKING PAPER 7/2017. UNIDO.

[7] Economic Commission for Africa (N. d). A Theoretical perspectives on industrial policy.

[8] Ernest S. (2013). Macroeconomic Variables and the Productivity of the Manufacturing Sector in Nigeria: A Static Analysis Approach. Department of Economics, Faculty of Social Sciences University of Lagos, Nigeria. Journal of Emerging Issues in Economics, Finance and Banking (JEIEFB) (ISSN: 2306 367X) Volume: 1 No. 5 pp, 362-380.

[9] Fantu, C. (2016). Structural Transformation in Ethiopia: The Urban Dimension. ECPI Discussion Paper Final Stockholm International Peace Research Institute.

[10] Granger, C. (1988). Causality, cointegration and control. Journal of Economic Dynamics and Control.

[11] Harris, R. (Harris, R. and Sollis, R. 2003). “Applied Time
Series Modelling and Forecasting”. West Sussex.

[12] Ibbih JM and Gaiya BA (2013). A cross-sectional analysis of industrialization and growth in Africa. International Research Journal of Arts and Social Sciences (xxx-xxx) Vol. 2 (6) pp. 150-167.

[13] Ireland, P. (2005). The monetary transmission mechanism. FRB of Boston Working Paper No. 06-1.

[14] Johansen, S. (1992). Testing Weak Exogeneity and the Order of Cointegration in UK Money Demand. Journal of Policy Modeling, 313-334.

[15] Kaldor, N. (1975). Economic growth and the Verdoorn Law: A Comment on Mr. Rowthorn's Article. Economic Journal, Vol. 85, Nr. 340.

[16] Kassahun, T. (2006). Dynamic Sectoral Linkages in the Ethiopian Economy: A preliminary Assessment. Addis Ababa: Ethiopian Economic Association/Ethiopian Economic Policy Research Institute (EEA/EEPRI).

[17] Katircioglu, S. (n. d). Co-Integration and Causality between GDP, Agriculture, Industry and Services growth in North Cyprus: Evidence from Time Series Data, 1977-2002. Review of Social, Economic \& Business Studies, 7/8, 173-187.

[18] Kindeye, F. (2014). Industry and Industrialization in Ethiopia: Policy Dynamics and Spatial Distributions. College of Development Studies, Addis Ababa University. European Journal of Business and Management. ISSN 2222-1905 (Paper) ISSN 2222-2839 (Online) Vol. 6, No. 34.

[19] Kumneger, T. (2018). The impact of FDI on the Ethiopian economic growth. Wollega University, Nekemte, Ethiopia. Unpublished thesis.

[20] Kutu, Adebayo Augustine and Ngalawa, Harold (2016): Monetary policy shocks and industrial output in BRICS countries, SPOUDAI - Journal of Economics and Business, ISSN 2241-424X, University of Piraeus, Piraeus, Vol. 66, Iss. 3, pp. 3-24.

[21] Landry S., Chelsea J. (2018). The potential of manufacturing and industrialization in Africa Trends, opportunities, and strategies. David M. Rubenstein Fellow, Africa Growth Initiative, Brookings Institution.

[22] Libiano G (N. D.). "Manufacturing Industry and Economic GrowthIn Latin America: A Kaldorian Approach," www.policyinnovations.org/ideas/policy_library/data/.

[23] Mandara, B., Ali, MB. (2018). Appraisal of the Impact of Industrialization on Economic Growth in Nigeria. Department of Business Education, Federal College of Education Yola, Nigeria. Journal of Business and Management (IOSR-JBM), p-ISSN: 2319-7668. Volume 20, Issue 1. Ver. V PP 01-10.

[24] Mishkin, F. S. (1995). Symposium on the Monetary Transmission Mechanism. Journal of Economic Perspectives, $3-10$.

[25] MoFED. (2010). Growth and Transformation Plan (GTP I) 2010/11-2014/15. Addis Ababa: Ministry of Finance and Economic Development ().

[26] Mollentze, S. L. (1997). The monetary transmission mechanism: The state of thought. Bureau for Economic Policy and Analysis, Department of Economics, University of Pretoria. 
[27] Montfort M., Larry C., Ahmat J., Monique N., Bozena RB., Misa T., Yanmin Y., Jiayi Z.(2016). Financial Development in Sub-Saharan Africa Promoting Inclusive and Sustainable Growth ISBN: 978-1-47553-240-1.

[28] Mordi, C. N. O. (2010). The link between the financial (banking) sector and the real economy. Central Bank of Nigeria Economic and Financial Review, 48 (4), pp. 1-12.

[29] Mulu Gebreeyesus (2013). Industrial Policy and Development in Ethiopia: Evolution and Current Performance. Helsinki, Finland.

[30] Naval, M. R. (2016). An Empirical study of Inter-Sectoral Linkages and Economic growth in India. American Journal of Rural Development, 4, 78-84.

[31] NPC. (2016). Growth and Transformation Plan II (2015/162019/20). Addis Ababa: National Planning Commission.

[32] Okoye, L., Clement N (2015) THE INFLUENCE OF FINANCE AND MACROECONOMIC VARIABLES ON MANUFACTURING CAPACITY UTILIZATION IN NIGERIA. The Official Journal of Nigerian Accounting Association Vol. 6, No. 1.

[33] Oqubay A. (2018). Industrial Policy and Late Industrialization in Ethiopia, Working Paper Series No 303, African Development Bank, Abidjan, Côte d'Ivoire.

[34] Patrick Enu, Prudence Attah-Obeng (2013) Which Macro Factors Influence Agricultural Production In Ghana? Legon, Ghana.

[35] Pesaran, M. H., and Pesaran, B. (1997). Working with Microfit 4.0: Interactive Econometric Analysis, Oxford University Press, Oxford.

[36] Pesaran. M, \&. S. (1999). An autoregressive distributed lag modeling approach to cointegration, analysis. Cambridge.: Cambridge University Press.

[37] Phillips, P. a. (1988). Testing for a Unit root in time series regression. Biometrika, 335-346.
[38] Rodrik, D. (2008), the Real Exchange Rate and Economic Growth, Brookings Papers on Economic Activity, fall 2008, pp. 365-412.

[39] Roseline Oluitan Financial Development and Economic Growth in Africa: Lessons and Prospects. Business and Economic Research. ISSN 2162-4860. Vol. 2, No. 2 doi: 10.5296/ber.v2i2.2205 http://dx.doi.org/10.5296/ber.v2i2.2205.

[40] Samantha N., Liu H.,(2018). The Effect of Foreign Direct Investment on Industrial Sector Growth: Evidence from Sri Lanka. P. R. China. Journal of Asian Development. ISSN 2377-9594 2018, Vo. x, No. x.

[41] Taddele, F. (2000, April). MEASURING SECTORAL INTERDEPENDENCE IN ETHIOPIA: A SOCIAL ACCOUNTING MATRIX (SAM) APPROACH. Ethiopian Journal of Economics, IX.

[42] Ubi, P., Lionel E., Eyo, E.(2012). Monetary Policy and Industrialization in an Emerging Open Economy: Lessons from Nigeria. International Journal of Academic Research in Business and Social Sciences. Vol. 2, No. 8 ISSN: 2222-6990.

[43] Udo, N. (2014). Nigeria Industrial Policies and Industrial Sector Performance: Analytical Exploration. Department of Economics, Akwa Ibom State University, Akwa Ibom State, Nigeria. IOSR Journal of Economics and Finance (IOSR-JEF). p-ISSN: 2321-5925. Volume 3, Issue 4.

[44] United Nations Trade And Development (2016). The CatchUp Challenge: Industrialization And Structural Change United Nations Conference On Trade And Development Geneva.

[45] Worku Gebeyehu, G. A. (2013). Which sector should lead in Ethiopia? Industry or Agriculture? Addis Ababa: Ethiopian Economic Association.

[46] Wubshet, O. (2008). The determinant of aggregate import demand in Ethiopia: co integration analysis. Addis Ababa, Ethiopia. 